\title{
Productive performance of York $x$ Landrace sows in a semi-technified farm
}

\section{Comportamiento productivo de cerdas York $x$ Landrace en una granja semi tecnificada}

SANCHEZ-CHIPRES, David Román†๋*, MORENO-LLAMAS, Gabriel, JIMÉNEZ-PLASCENCIA Cecilia and JIMÉNEZ-CORDERO, Ángel Andrés

Animal Production Departament, CUCBA, Universidad de Guadalajara

ID $1^{\text {st }}$ Author: David Román, Sanchez-Chipres / ORC ID: 0000-0002-5273-0393, CVU CONACYT ID: 69431

ID $1^{\text {er }}$ Co-author: Gabriel, Moreno-Llamas / ORC ID: 0000-0002-1003-1738, CVU CONACYT ID: 101392

ID $2^{\text {do }}$ Co-author: Cecilia, Jiménez-Plascencia / ORC ID: 0000-0003-1705-792X, CVU CONACYT ID: 1000339

ID $3^{\text {er }}$ Co-author: Ángel Andrés, Jiménez-Cordero / ORC ID: 0000-0002-1734-2678, CVU CONACYT ID: 947963

DOI: 10.35429/JQSA.2021.22.8.18.24

Received September 05, 2021; Accepted December 05, 2021

\begin{abstract}
The aim of this work was to evaluate the productive performance of sows in a semitechnified farm. Sows were F1 York x Landrace inseminated with Pietrain. For the study, we considered 13 litters of the same age. It was recorded number of piglets born, weight at birth and at weaning, as well as number of piglets weaned. The information was recorded in the Pigchamp@ program. When analyzing all the information regarding litter size and litter weight, compared with other studies, the data obtained in this work is good. With all the variables recorded, we observed a high and positive correlation, similar to Murillo et al. (2017) results. The use of these variables as indicators of maternal productivity increases with each sow calving.
\end{abstract}

Production, Piglets, Temperature

\begin{abstract}
Resumen
El propósito de este trabajo fue evaluar el comportamiento productivo de cerdas F1 York x Landrace inseminadas con sementales Pietrain, en una granja semi tecnificada. Se tomaron en cuenta 13 camadas de la misma edad. Se obtuvo información de lechones nacidos, peso de lechones al nacimiento y destete, lechones destetados y días de lactancia. Los datos se registraron en el programa Pigchamp@) El análisis de los registros sobre tamaño de camada y peso de camada, comparados con otros estudios, muestra que los resultados del presente trabajo son comparables. Las correlaciones calculadas entre las diferentes variables, indican que hubo valores positivos, similar a los resultados de Murillo et al. (2017). El análisis de estas variables como indicadores de productividad materna, indica mejora con cada parto.
\end{abstract}

Producción, Lechones, Temperatura

Citation: SANCHEZ-CHIPRES, David Román, MORENO-LLAMAS, Gabriel, JIMÉNEZ-PLASCENCIA Cecilia and JIMÉNEZ-CORDERO, Ángel Andrés. Productive performance of York x Landrace sows in a semi-technified farm. Journal of Quantitative and Statistical Analysis. 2021. 8-22: 18-24

$\dagger$ Investigador contribuyendo como primer autor. 


\section{Introduction}

Annual meat pork consumption in Mexico grew at an annual rate of $3.9 \%$; estimated increase was from 1.4 million tons in 2006 to 2.1 million tons in 2018. It is expected this trend will continue in 2019 , to achieve a consumption of 2.2 million tons, $4.3 \%$ of annual increase. In the 2014-2018 period, $69 \%$ of the pork meat consumption, came from the national production, the rest was imported. Pork meat is a less expensive alternative than other meats in Mexico. Jalisco is an important pork meat producer; it ranked the third nationwide in the last 30 years. Jalisco production in 2018 was 321,735 tons of pork meat (SAGARPA-SIAP, 2019).

There are four specialized regions for swine production: Northern High Lands (Lagos de Moreno, Jalisco, county as the center of the region), Southern High Lands (Tepatitlán County), South (Ciudad Guzmán County) and Central (Zapopan County). Northern and Southern High Lands are the most important regions, with $85.6 \%$ of the total pork population, 3,413,513 animals (INEGI 2016). Classification of the swine production systems in Jalisco are intensive, semi-intensive and extensive. The three production types coexist in Jalisco, although the predominant ones are the semiintensive systems.

This classification depends on the level of technology for environment and animal management. These animal populations are denser and more confined in the intensive production models. Organization and operation of the intensive production systems work according to the capital model, which means more work and profit in the shortest time possible. This is only feasible to the extent that there is standardization in every link in the production chain, to ensure a commercial product uniformity. Such a model needs high tech. The essential resource in the system is the swine, and to guarantee the productive dynamics there are necessary populations with uniform traits. Achievement of this goal requires genetically homogeneous animals, as the result of high selection pressures. It is also necessary a stable and comfortable environment; this way the strength levels of the intensive, semiintensive or extensive animal production systems, are defined when it is established the levels of environmental control (POET, 1998).
Intensive and semi intensive production is the majority of Jalisco farms system. The usual genetic background in these farms are interracial hybrids, although not all come from schemes of planned crossings. Frequently, the breeding grounds of different racial genotypes come from countries as Canada, United States or England.

Jalisco swine farmers are looking for technological changes to achieve higher efficiency in their production processes. They are trying to obtain pigs in 21 weeks with a market weight of 100-110 kg. Improvement of food quality and the breeding systems are the commonly used advances in technified farms. Pork producers pursue a daily increase through genetic breeding, but in Jalisco, there is not a standardized production scheme that take in account the crossing races. Female lines are usually F1 Yorkshire x Landrace, Yorkshire $\mathrm{x}$ Hampshire, Large White $\mathrm{x}$ Landrace or Landrace $\mathrm{x}$ Hampshire. As males, the most frequent races are Duroc, Hampshire, Pietrain, or hybrids of these races (Flores y Gómez, 1995). This leads to producing swine with differences in reproductive performance, feeding efficiency, adaptation to several environmental factors, etc. It is evident when comparing the in country animals with imported ones, there is a difference of $0.6-0.7 \mathrm{~kg}$ in piglets at birth and $0.6 \mathrm{~kg}$ in weaned piglets (Batista, 2000).

\section{Problem approach}

Reproductive traits present a low heritability; to achieve much of the improvement goals it is necessary to reinforce good management practices, as well as housing systems and climatic conditions that influence the sow's productive performance. Not to carry out these activities, result in an underutilization of the sow, and will limit the possibility of genetic improvement of the herd.

\section{Justification}

Currently farms require a higher productivity to maintain financial efficiency. The sows are the base to keep high productive parameters, so it is necessary to provide environmental conditions to express their reproductive capacity. Information and analysis thereof shall enable to identify improvement areas in the farm. 


\section{General Objective}

Evaluate the productive performance of sows in a semi-technified farm.

\section{Particular Objectives}

Evaluate parameters of live-born piglets, weaned piglets and piglets weight at weaning; correlate parameter effects on litter size at birth and at weaning, the number of births per female, number of weaned piglets per female.

\section{Materials and methods}

\section{Location}

The study was carried out in December 2017 to January 2018, in a commercial farm in the Zacoalco de Torres County, state of Jalisco. It is a semi-technified farm with 230 bellies.

\section{Animals}

It was considered 13 litters of (York x Landrace) $\mathrm{x}$ Pietrain.

\section{Studied variables}

Five variable records were made of the 13 litters: mortality, weaned piglets, litter weight at weaning and lactating days.

\section{Experimental methodology}

The study included thirteen contemporary litters. It was recorded litter size at birth, mortality, litter weight at birth and at weaning, weaned piglets, and lactating days. Data was recorded with Pigchamp $\odot$ software. It was also recorded four types of temperatures around the litters during the first 28 days of life: maximum, minimum, average and midpoint, with a Fluke ${ }^{\circledR}$ thermograph.

\section{Experimental design}

Regression analysis of the productive data was done in order to understand the relation between them, and with temperatures (Steel and Torrie, 1960).

\section{Results}

More relevant results are included in this section. Table 1 shows the litter's information from birth to weaning, compared to the average environmental temperature in which the piglets lived the first 28 days.

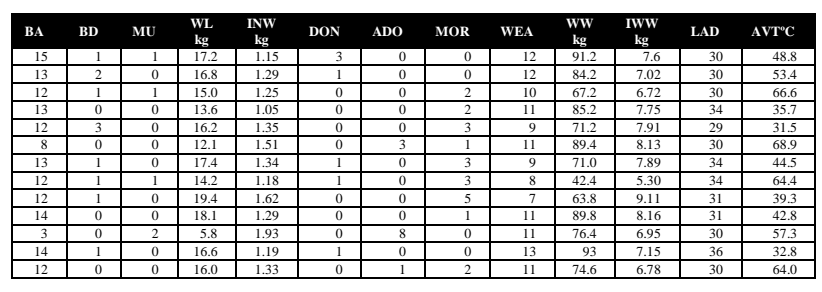

$\mathrm{BA}=$ born alive $; \mathrm{BD}=$ born dead $; \mathrm{MU}=$ number of mummies; $\mathrm{WL}=$ litter weight at birth; INW = piglet individual weight; $\mathrm{DON}=$ donations; $\mathrm{ADO}=$ adoptions; $\mathrm{MOR}=$ mortality $; \mathrm{WEA}=$ weaned piglets; $\mathrm{WWE}=$ litter weight at weaning; IWW = individual weight at weaning; $\mathrm{LAD}=$ lactating days; $\mathrm{AVT}=28$ days average temperature.

Table 1 Production record of 13 sows from birth to weaning

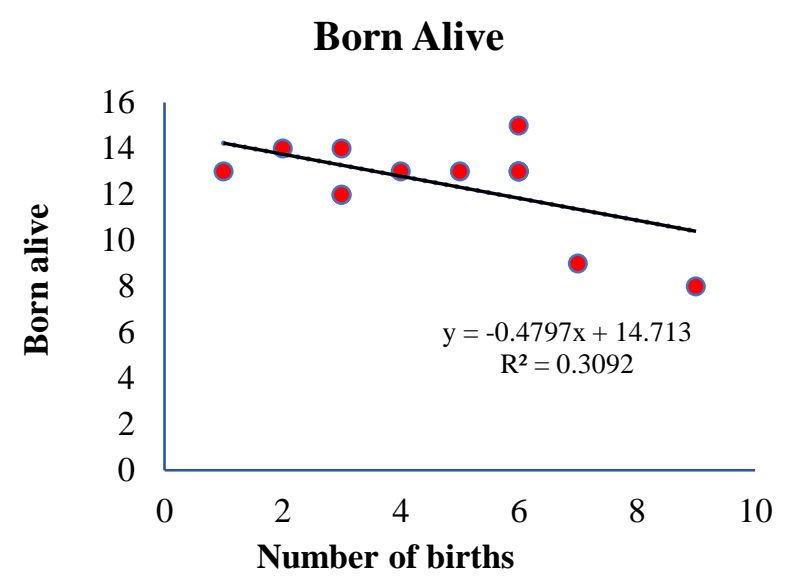

Graph 1 Regression between the number of births and piglets born alive

Graph 1 shows the equation and the regression line between the sows' number of births and piglets born alive. The image indicates that as the number of sows' deliveries increases, the amount of live piglets born decreases. 


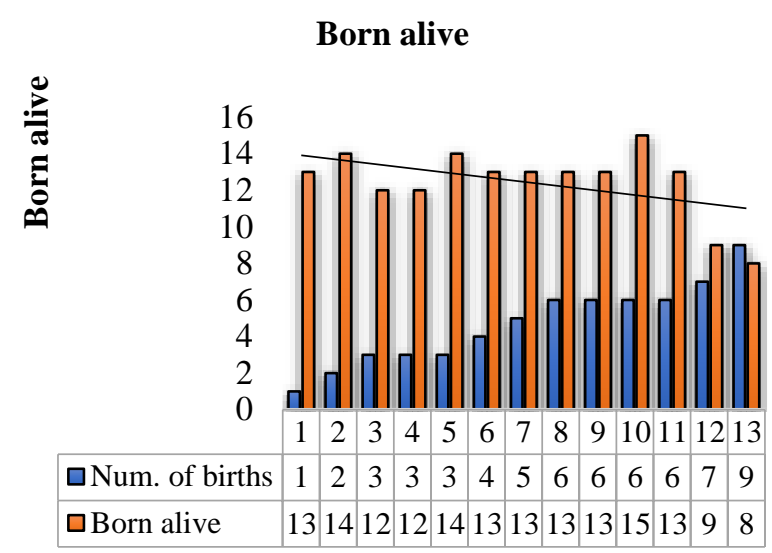

Number of births

Graph 2 Number of births and piglets born alive

The determination coefficient indicates that the number of births influenced negatively in $31 \%$ the amount of piglets born alive. Bars in graph 2 represents the relation between the number of births and the number of piglets alive. Although there is certain variation for piglets born alive and the number of the sow births, there is a negative trend, particularly from the seventh delivery onwards.

\section{Litters weight at born}

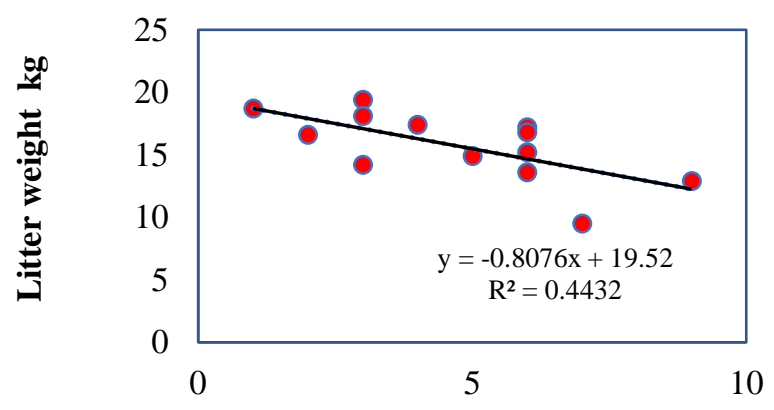

Number of births

Graph 3 Regression between the number of births and litter weight at born

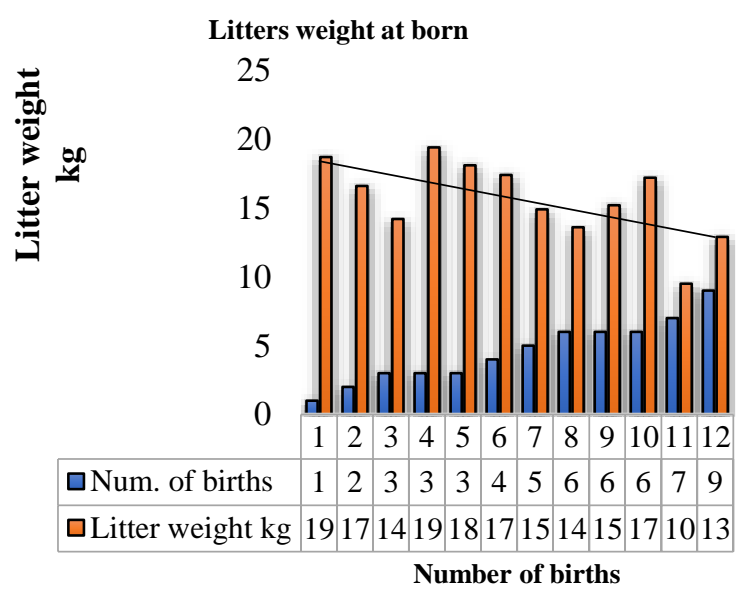

Graph 4 Number of births and litters' weight
Graphs 3 and 4 shows the equation and the regression line between the sows' number of births and the litter weight. This information indicates as the number of the sows' deliveries increases, the piglets' weight decreases. With the exception of litter 10, form the fifth birth onwards the litter weight declines. The coefficient of determination indicates that $44 \%$ of the litters' weight received a descendent effect according to the sows' births.

\section{Litter weight at weaning}

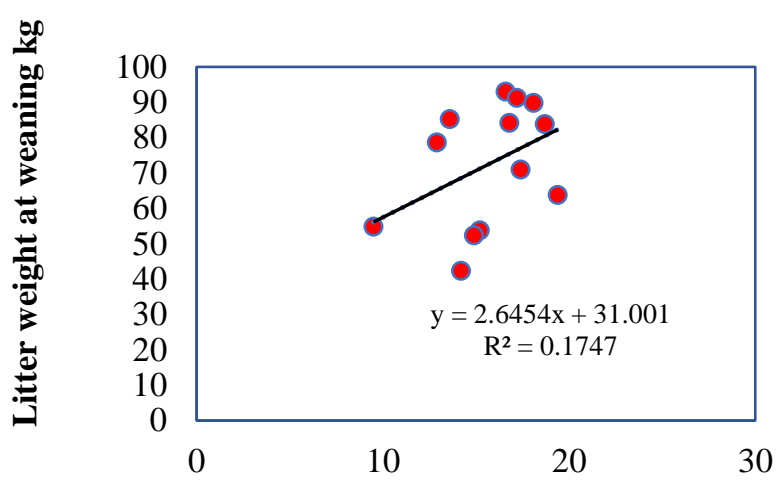

Litter weight at born $\mathrm{kg}$

Graph 5 Litter weight at born and at weaning

Graphs 5 and 6 have the equation and the regression line between litters weight and weight at weaning. There is a positive but weak influence of the litters' weight at birth in the piglets' weight at weaning, as shown by the determination coefficient $\left(R^{2}=0.1747\right)$.

\section{Weight at weaning}

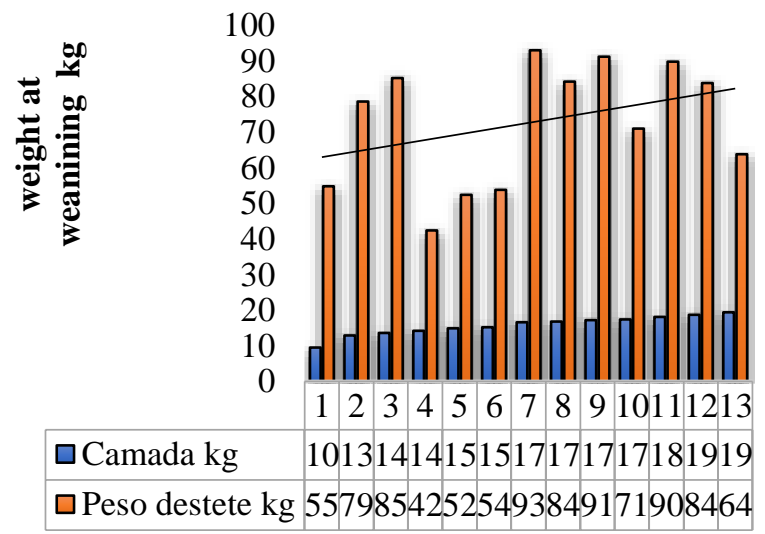

Litter weight at born $\mathrm{kg}$

Graph 6 Regression between litters' weight at born and weight at weaning

Graph 6 represents the relation between litters weight and the respective weight at weaning. 
Variation observed between litters, particularly litters $4,5,6$ and 13 , makes the $\mathrm{R}^{2}$ coefficient low, although there is a positive trend, as seen in the adjusted values of the line.

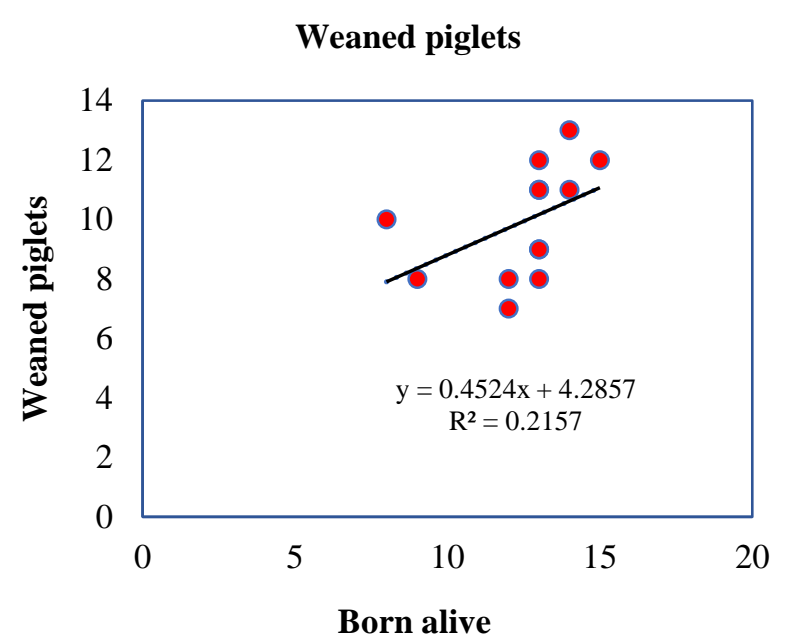

Graph 7 Regression between weaned piglets and born alive

Graph 7 and 8 contains the equation and the regression line between number of piglets born alive and weaned animals. There is a positive trend when observing the number of piglets weaned and the ones born alive, although there is a weak $\mathrm{R}^{2}=0.2157$.

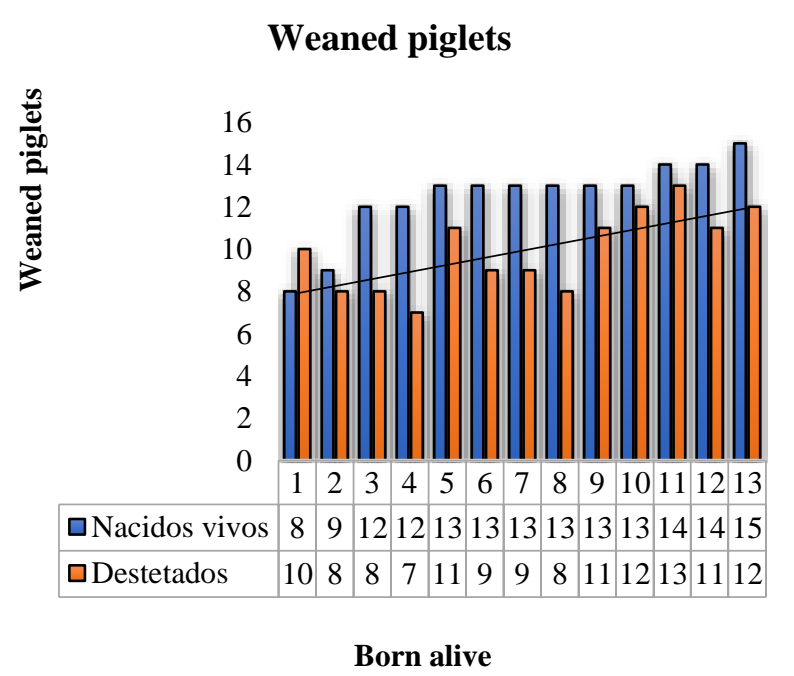

Graph 8 Regression between piglets born alive and weaned animals

Table 2 contains the multiple regression equations and their respective determination coefficients, to illustrate the interrelationship between initial aspects of sows' litters, as indicated in the table, with the rest of the variables recorded. $\mathrm{R}^{2} \mathrm{~s}$ obtained indicate an influence of the four variables (b1 to b4) at the start of life of piglets on subsequent production characteristics.
December, 2020 Vol.7 No.21 18-24

\begin{tabular}{c|l|l|}
$\begin{array}{c}\text { y } \\
\text { trait }\end{array}$ & $\hat{\mathbf{y}}=\mathbf{a}+\mathbf{b 1}(\mathbf{x})+\mathbf{b 2}(\mathbf{x})+\mathbf{b 3}(\mathbf{x})+\mathbf{b 4}(\mathbf{x})$ & $\mathrm{R}^{2}$ \\
\cline { 2 - 3 } MOR & $\begin{array}{l}\hat{\mathrm{y}}=19.62-0.18-1.74+1.18 \\
-11.0\end{array}$ & 0.43 \\
\cline { 2 - 3 } WEP & $\begin{array}{l}\hat{\mathrm{y}}=-7.48+0.14+1.86-1.21 \\
+10.3+0.32\end{array}$ & 0.32 \\
\cline { 2 - 2 } & $\hat{\mathrm{y}}=6.93-0.15-0.31+0.33-0.20+0.47$ & 0.47 \\
\cline { 2 - 3 } LAC & $\hat{\mathrm{y}}=13.8-0.11+2.2-1.29+9.16+0.42$ & 0.42 \\
\hline
\end{tabular}

$\mathrm{MOR}=$ mortality; $\mathrm{WEP}=$ weaned piglets; $\mathrm{IWW}=$ individual weaned weight; $\mathrm{LAC}=$ lactating days

Table 2 Multiple regressions between deliveries (b1), piglets born alive (b2), piglets' litter weight at birth (b3), and individual weight at birth (b4) with other productive traits related (y's)

\section{Heat source average temperature}

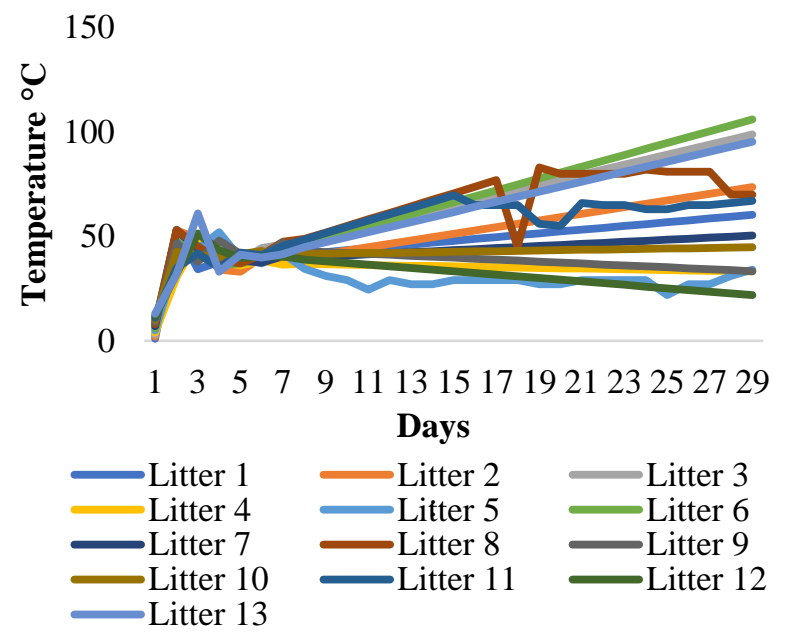

Graph 9 Twenty eight days average temperatures in the maternity area

Graph 9 shows ambient temperatures in the maternity area for the first 28 days of the lactating period. Table 3 contains correlation coefficients between such average temperatures and productive traits recorded.

\begin{tabular}{|c|c|c|c|c|}
\hline & $\begin{array}{l}\text { Mean } \\
\text { temp. }\end{array}$ & $\begin{array}{l}\text { Min. } \\
\text { temp. }\end{array}$ & $\begin{array}{l}\text { Mid-point } \\
\text { temp. }\end{array}$ & $\begin{array}{l}\text { Max. } \\
\text { temp. }\end{array}$ \\
\hline MOR & -0.15 & -0.04 & 0.40 & 0.20 \\
\hline WEP & 0.05 & -0.23 & -0.08 & 0.35 \\
\hline NW & 0.31 & -0.25 & -0.08 & 0.40 \\
\hline IWW & -0.52 & 0.04 & 0.30 & 0.45 \\
\hline LAC & -0.40 & 0.23 & 0.30 & -0.10 \\
\hline
\end{tabular}

individual weaned weight; $\mathrm{LAC}=$ lactating days.

Table 3 Correlation coefficients between productive traits and ambient temperatures 


\section{Discussion}

Having regard to the information on all sows in this study, litter size and weight at birth, can be considered relatively good results compared to those obtained in other studies (Segura et al., 2007). Although differences are not great, it is evident the greater the number of births, the smaller the litter; in studies where the difference in favor of females with two or more deliveries has been significant, it has been explained due to the largest uterine size capacity, ovulation rate and embryo survival (Ruiz and Johnson, 2001). In a similar way, Koketsu et al. (1997), observed a better reproductive performance in sows with equal or more than two deliveries compared to the ones in first birth. PDE was different due to the amount of piglets per sow, nevertheless, their weight allows the pig to be viable after breastfeeding.

This condition can be result of similar management and nutrition during the lactating period, and the homogenization of litters at delivery. When weaning at same age, the litter weight depends primarily on the number of weaned piglets. Ordaz et al. (2013) reported an increased PCD ( $>>0.05)$ as the lactating period was prolonged, in $40.32 \pm 1.35 \mathrm{~kg}$ with lactations of one to seven days, until $64.01 \pm 0.52 \mathrm{~kg}$ with lactation periods equal or larger than 29 days.

\begin{abstract}
The influence of temperature in the maternity facility, showed mid-point temperature was the more stable one during the period studied, and in addition to maximum temperature, provided the best correlation with most productive traits. Results indicated there is a definite correlation between deliveries, piglets born alive, piglets' litter weight at birth, and individual weight at birth with other important variables studied, occurring at the end of the studied production cycle. These results are similar to those found by Murillo et al. (2007), which means these indicators are useful to evaluate the maternal productivity, increasing in each delivery.
\end{abstract}

The use of thermography to determine the temperature of heat sources, contributes to minimizing the handling of piglets, allowing them to devote their energy to finding their optimum temperature and food. This allows a faster growth in grams day ${ }^{-1}$.
It also allows environmental suitability for sows, as an inadequate temperature can decrease milk production, among other things. The knowledge on the environmental condition of the females will allow improving the efficiency of the biological behavior of sows and piglets.

\section{References}

Batista, L., 2000. Importancia de la evaluación de parámetros reproductivos. V Simposium Internacional de Reproducción e Inseminación Artificial en Porcinos. Ed. Alberto Stephano. 109-114.

Flores, J. J., y Gómez M. A., 1995. Alternativas para el desarrollo de la porcicultura jalisciense. La producción porcícola en México. Contribución al desarrollo de una visión integral. Luis Kato Coordinador. UAM.

Kato, L., 1995. Producción porcícola intensiva. En Kato, L. La producción porcícola en México. Universidad Autónoma Metropolitana. México 30-34.

Koketsu Y, Dial GD, King VL. 1997. Influence of various factors on farrowing rate on farms using early weaning. J Anim Sci. 75:2580-2587. INEGI (Instituto Nacional de Estadística Geografía e Historia). Censo Agropecuario 2016.

Murillo, C.; Herradora, M. A.; Martínez, R. 2007. Relación entre la pérdida de grasa dorsal de cerdas lactantes con el consumo de alimento, tamaño de la camada, peso de los lechones al destete y días de lactancia.Rev. Cientif. FCVLUZ. XVII (4): 380-385.

Ordaz-Ochoa, G.; Juárez-Caratachea, A.; García-Valladares, A.; Pérez-Sánchez, R.E.; Ortiz- Rodríguez, R. 2013 Efecto del número de parto sobre los principales indicadores reproductivos de las cerdas. Rev. Cientif. FCVLUZ. XXIII (6):511-519. 2013.

Proyecto de Ordenamiento Territorial del Estado de Jalisco (POET). 1998. Descripción y diagnóstico de la actividad pecuaria en Jalisco. Grupo pecuario. Universidad de Guadalajara. 11-15. 
Ruiz-Flores A, Johnson RK. 2001. Direct and correlated responses to two-stage for ovulation rate and number of fully formed pigs in swine. $\mathbf{J}$ Anim Sci. 79:2286-2297.

Secretaría de Agricultura y Desarrollo Social (SADER) Servicio de Información Agroalimentaria y Pesquera (SIAP) https://nube.siap.gob.mx/cierre_pecuario/

Segura CJC, Alzina-López A, Solorio RJL. 2007. Evaluación de tres modelos y factores de riesgo asociados a la mortalidad de lechones al nacimiento en el trópico de México. Tec Pecu Méx. 45:227-236. 